\title{
How Do First Year University Students Use ICT in Their Leisure Time and for Learning Purposes?
}

\author{
Ludvík Eger', Łukasz Tomczyk²*, Milan Klement ${ }^{3}$, Mária Pisoňová4, Gabriela Petrová ${ }^{5}$
}

\author{
1 University of West Bohemia, Faculty of Economics, Plzen, Czech Republic, e-mail: leger@kmo.zcu.cz \\ ${ }^{2}$ Pedagogical University of Cracow, Institute of Educational Science, Cracow, Poland, e-mail: lukasz.tomczyk@up.krakow.pl \\ 3Palacky University Olomouc, Faculty of Education, Department of Technical Education and Information Technolo-gy, Czech \\ Republic, e-mail: milan.klement@upol.cz \\ ${ }^{4}$ Comenius University in Bratislava, Faculty of Education, Slovakia, e-mail: mpisonova@ukf.sk \\ ${ }^{5}$ Constantine the Philosopher University in Nitra, Faculty of Education, Department of Pedagogy, Slovakia, \\ e-mail: gpetrova@ukf.sk
}

\begin{abstract}
This study advances our understanding of the current use of social media and mobile devices by first year university students. This research sought to explore the influence of the use of social networks and new mobile devices by students for learning purposes. Data were collected using a self-report questionnaire at four universities in three countries in Central Europe. The research was completed by a sample of 961 full-time first year undergraduate students. The data were analysed using descriptive statistic and confirmatory factor analysis. The findings show that students who intensively use ICT for leisure-related tasks are also experienced in ICT for learning purposes. Furthermore, the results showed differences in the use of ICTs according to four selected areas: ICT for leisure-time activities, social networking, ICT on mobile phones, and ICT for study purposes by students. Five well-differentiated clusters were identified by through cluster analysis, which we term the 'mobile subgroup', 'educational subgroup', 'social subgroup', 'network subgroup', and 'entertaining subgroup'. Educators can benefit from the results through a more complete understanding of how first year university students use social networks and mobile devices and how intensity in these areas influences ICT use for learning purposes.
\end{abstract}

Keywords: ICT competence, university students, social networks, mobile devices, leisure-time activities.

\section{Introduction}

Social networks are spreading rapidly with millions of users, especially among young people in the EU countries. Use of social networks in the educational process can be considered a potentially powerful educational tool because today's students spend much time in online networking activities practically every day. Previous research has shown that social network Sites (SNS) "support educational activities by enabling interaction, cooperation, active participation, information and resource sharing, and critical thinking" (Ajjan and Hartshorne, 2008; Areepattamannil, and Santos, 2020; GoldsmithPinkham and Guido, 2013; Selwyn, 2007, Mazman and Usluel, 2010). Students today demand more independence, networking, interaction, and opportunities in their learning and some of them consider Learning Management Systems a traditional and conservative learning tool (Forouzesh, and Darvish, 2012; Oureshi, Raza, and Whitty, 2015).

These days, university students are also integrating mobile devices into their learning process that provide them informal and non-formal learning contexts and encourage their orientation to immediate communication and collaboration. Integration of emerging social media, including networks, and mobile devices into existing learning practices significantly facilitates more robust educational opportunities (Harris, 2015; Mazman and Usluel, 2010; Picatoste, Pérez-Ortiz, and Ruesga-Benito, 2018; Sung, Chang, and Liu, 2016). Educators and students would benefit from a more complete understanding of the role of SNS in promoting but also hindering students' academic success (Flanigan and Babchuk, 2015; Lau, 2017, Wakefield, and Frawley, 2020). For today higher education students is important knowing how to use ICT, including social media and mobiles, to learn, communicate, share and work with ideas. "Digital competence is recognised as one of key competences for lifelong learning" (Measuring Digital Skills across the EU, 2014) and its development is an essential part of preparing young people for leisure,

\footnotetext{
“Corresponding author: lukasz.tomczyk@up.krakow.pl
} 
learning, work and communication in knowledge society.

The rapid development of ICT has had considerable and visible impact on current educational sector (Flanigan and Babchuk, 2015; Goodfellow, 2011; Juhaňák et al., 2019; Mazman and Usluel, 2010; Stošić and Stošić, 2015; Wu and Tsai, 2006). In the last two decades, researchers have largely explored learners' attitudes toward new media. However, comparatively few studies have investigated students' attitudes towards using the Internet for different purposes in their formal and informal learning. This especially applies to the countries of Central Europe, where the dynamic development of ICT use started later than in the Western European countries (Eger and Egerova, 2013; Klement, 2013; Tomczyk and Kopecký, 2016; Slechtova, 2015). Therefore, one of the major purposes of the present study is to assess first year university students' ICT attitudes with a special focus on the use of SNS and mobiles (smartphones for communication purpose). Our next aim is to provide a deeper understanding of how first year university students really use ICT in their daily life.

\section{Literature review}

\section{ICT education in the Czech Republic, Poland, and Slovakia}

Despite the fact that the Czech Republic, Slovakia, and Poland can be classed as relatively young EU countries, their educational systems have a long tradition. ICT education in various forms has become an obligatory part of the curriculum in all three of these countries, which joined the EU together in 2004. However, the attitudes towards ICT education are not uniform in all these countries. The new national curriculum reforms, which included competence-oriented information education in primary and secondary education, including teachers' professional development, have laid solid foundations for the use of ICT at universities as well (Kiss, 2017; Klement, 2017; Plebańska, 2017; Půžová and Marešová, 2014; Tomczyk et al., 2015). Information education tends towards the building of information and ICT literacy with special emphasis on eliminating the emergent digital divide between individuals and groups differing in access to technology (Benes et al., 2008; Digital Divide.org., 2008). In these countries, schools play a key role in delivering ICT training. Also, internet penetration of society (ICT Development index, 2017), household equipment with ICT, and experience with new media use at home (Eurostat, 2020), at work, or in leisure various activities are very important.

\section{Social networks, mobiles, and their place in learning}

SNS, consisting mostly of young users, become an informal environment which plays an key role in continuing education and in interactions and collaboration outside the school. The research findings show that for university students could be using of social networks attractive also in an academic context (Ali et al., 2017; Gikas and Grant, 2013, Wakefield and Frawley, 2020). Moreover, some researchers argue that we are only at the beginning of research on problematic and non-problematic users' behaviour on social networks (Kim and Yang, 2017; Marino et al., 2017). SNS are user-friendly technologies that allow students to view, rapidly update, analyse, produce and spread information. It is an environment that establishes spontaneous relationships and supports not only formal but also informal learning activities.

"There are now more than 3.8 billion social media users around the world, representing 49 percent of the world's total population" (weaersocial.com, 2020). Age has been found to be an important factor determining differences in the internet lifestyle. Among younger users in the EU aged 16 to 24 years) some of the most popular online activities in 2016 included participating in SNS (88\%), watching videos from YouTube or Netflix (83\%), and listening to music (80\%) (Digital Economy and Society in the EU, 2017).

Nowadays, the most popular SNS for college students in the Visegrad countries are Facebook and Instagram (Eger et al., 2020). Approximately one-third of Facebook users are aged between 25 and 34 years and most Instagram users are between 18 - 29 years of age (Stout, 2020). The most popular social media for students at higher education is Facebook, which had more than 2.5 billion active users worldwide. Some surveys have shown positive correlations among the use of social networking sites and student involvement (Chou and Pi, 2015; Gaudreau, Miranda, and Gareau, 2014). On the other hand, some studies (e.g. Flanigan and Babchuk, 2015) warn of potential technological distractions and their influence on academic performance. 


\section{ICT self-efficacy}

In general, ICT self-efficacy comprises computer and internet self-efficacy (Pagastergiou, 2010) and is defined as a personal assessment of a person's ability to use ICT (Aesaert et al., 2017); it is measured as the level or extent of her or his belief in the use of a computer and the Internet. Many studies assessing ICT competences apply measures of ICT self-efficacy to assess the students' actual level of ICT competence (cf. Rothagi, Scherer and Hatlevik, 2016). ICT self-efficacy is a concept that originates from the construct of self-efficacy, which derives from Bandura's Social Cognitive Theory (Bandura, 1996). ICT self-efficacy refers to students' self-confidence in solving basic and advanced tasks related to new media (ICILS, Fraillon et al., 2015) when asked how well they believe in the ability to perform ICTrelated tasks (Scherer et al., 2017).

Internet self-efficacy (also SNS and mobile learning) shows the self-confidence and expectations of users in using the Internet, social media and mobile phones. It has been suggested that students with high expectations of effectiveness may be more likely to succeed in both computer and Internet related tasks (Tsai and Tsai, 2003; Wu and Tsai, 2006). Self-efficacy applies to all areas of human activity, including ICT use. In our research we combine computer self-efficacy and Internet self-sufficiency into one concept.

\section{The relation between ICT use, self-efficacy, ICT literacy, and ICT competence}

The above-mentioned information about students' ICT self-efficacy and students' ICT use and their engagement brings us to a partial conclusion. Scherer, Rohatgi and Hatlevik (2017, p. 488) argue: "Reviewing existing literature with respect to the relation between the use of ICT and students achievement in general, researchers have come to realize that there is mixed evidence..... It seems reasonable to assume that there exists a relation between students' experience and mastery of ICT use in different contexts, and students' computer and digital literacy, which students express as their self-efficacy in ICT skills (cf. Rohatgi, Scherer and Hatlevik, 2016; Siddiq, Cochyyev and Willson, 2017). It is also important to consider differences between subgroups of students when describing the use of ICT (Eger et al, 2018). Average ICT use by higher education students probably obscures "the fact that students do not equally exploit the opportunities offered by an almost complete availability of digital resources" and the opportunity to use ICT as tool for learning purpose (Scherer et al., 2017).

It should be noted that Aesaert et al., (2017) emphasise that "research indicates that bias and accuracy of self-efficacy need to be considered when studying the relationship between self-efficacy and actual performance". Thus, many research studies assessing "ICT competences use measures of ICT self-efficacy to assess students' actual level of ICT competence". Therefore, we consider a given assessment of student' answers more valid if the questions are not focused on how well they believed they could perform computer- and Internet-related tasks, but rather on how often they actually use selected computer- and Internet-related activities in their life for different purposes (cf. Juhaňák et al., 2019). Of course, we need to take into account that "successful performance is stimulated by accurate self-efficacy" (Bandura, 1986). Research by Siddiq et al., (2017) on ICT literacy has documented positive and significant correlations between students' digital competence and self-efficacy.

Computer and information literacy and digital literacy (belonging to key competences, are considered as convergent terms, in many cases synonyms) is described as students' achievements with information and communication technology in different context, as an "ability to use computers to investigate, create and communicate in order to participate effectively at home, at school, in the workplace, and in society" (Fraillon et al., 2015, 17). It also means, the ICT literacy cannot be defined primarily as the mastery of technical skills. "ICT literacy comprises the abilities to process digital information, communicate with others, and solve given problems". Digital competence is constantly being developed. The development of the information society requires the improvement of these skills (Rohatgi et al., 2016; Tomczyk and Oyelere, 2019; Arteaga et al., 2020).

"The importance of digital competence was recognised by the European Parliament and the European Council in 2006" (Measuring Digital Skills across the EU, 2014). We do not use this broad concept in conducted research, but following Rohatgi et al., 2016 conclusion that ICT literacy and digital and information literacy are "slightly different conceptualizations of being competent with ICT, we use these two terms interchangeably" in this research (cf. Rohatgi et al., 2016). Competency can be related to students' success in the performance of related tasks because a certain degree of digital literacy is a necessary prerequisite in order to use digital technology autonomously (Juhaňák et al., 2019). This paper follows Hatlevik, Gudmundsdóttir and Loi (2015) is understanding ICT "competence as the skills, knowledge, and attitudes that enable students to use digital media for participation, work, and problem 
solving independently or in collaboration with others in a critical, responsible, and creative manner".

\section{Research questions and hypothesis}

On the basis of our theoretical considerations and information about education and ICT development in the three aforementioned countries, the present research is aimed at answering the following research questions:

- How do university students use ICT in their life and for learning?

- Is an overall high use of ICT across almost all areas of life typical of all university students?

- To what extent do they use computers and Internet for e-learning?

Specifically, we expect a positive impact of the level of students' ICT self-efficacy in mobile phone and SNS use on ICT use for e-learning purpose. This assumption is in line with information about the level of ICT education and ICT literacy at secondary schools in the Czech Republic, Slovakia, Poland and the ICT development index of these countries. This argument has also been discussed on a more general level in studies and conceptual documents, and a positive association has been identified in numerous studies (e.g. Junco, 2012; Rohatgi et al., 2016; Wu and Tsai, 2006).

- Hypothesis 1: There are no significant differences in the use of mobiles and social networks among groups of first year students from the Czech Republic, Slovakia, and Poland.

Hypotheses 2 and 3 suggest that students' use of social media and mobiles (smartphones) can play a new role in their learning process. The percentage of students who SNS is high and some studies have found "positive correlations between social networking website use and college student engagement" (Chou and Pi, 2015; Gaudreau, Miranda, and Gareau, 2014). Average ICT use by university students probably hides the fact that students do not use ICT for school and home-related tasks equally (Scherer et al., 2017). It is important to distinguishing between subgroups of students when describing their use of ICT.

- Hypothesis 2: ICT use and the level of ICT self-efficacy of first year university students is positively related to their use of ICT for learning purposes.

- Hypothesis 3: First year university students do not use ICT in their life as a homogenous group of young people, but rather there are subgroups of students characterized by their use of ICT.

\section{Method}

This research was conducted to explore university students' self-efficacy toward ICT use with a special focus on the use of social networks and mobile devices for learning (cf. Flanigan and Babchuk, 2015; Lau, 2017; Wu and Tsai, 2006). The purpose of this paper was to fill a gap in the literature by using samples of university students from three countries of Central Europe to examine the relationship between the frequency of SNS and mobile use and their participation in learning- related activities and student engagement (Junco, 2012).

\section{Research instrument}

The research was inspired by the ICILS (Fraillon et al., 2015), Eurostat (2017) Digital skills of individuals, European Commission: Survey of Schools: ICT in Education (2013), Salomon and Kolikant (2016), and Rothagi et al. (2016). The development of the instrument started with the designation of particular measurement instruments (cf. Eger et al, 2018). One important feature of the instrument is its focus on the 'doing' approach (cf. Lee, Chen and Lin, 2015). The items balance generality and specificity. For example, a general item is 'I communicate on social networks', and a specific item is 'I am sending photos from my cell phone.' For both items we use a 5-point Likert scale (never=1, always=5). In our case, the student might know how to send a photo from a cell phone, but if he/she never does it at all, he/she does not display competence in this sub-area.

The establishment of content validity was achieved by the inclusion of a panel of four experts from three countries in three roundtable discussions to decide the appropriateness of the content of items. The experts were university teachers with Ph.D. degree, ten years experience in implementation of ICT or in innovation of teaching and learning process and with experience in cooperation with high schools. A first pilot test with 10 first year university students was conducted for the purpose of checking the pilot questionnaire and ensuring that respondents had no problems understanding the questions and following all the instructions correctly. Data were collected using a self-report questionnaire in both forms (self- 
administered and online forms). The questionnaire used the following four scales of students' ICT use (see Table 1 A-D) for different purposes (use of ICT for leisure-time activities, use of SNS, use of mobile phones, and use of ICT for learning purpose).

The reliability of the instrument was established by an appropriate level of internal consistency (Cronbach's alpha). The value of Cronbach's alpha for all 25 items is 0.835 , which is evidence of internal consistency reliability (Nunnally and Bernstein, 1994). Therefore, the reliability of the research instrument was fully validated. The whole tool has also been evaluated through Exploratory Factor Analysis (EFA). The results are presented in Annex 1.

\section{Sample and procedure}

The convenience sample in our study was composed of students from the academic courses of four universities in three countries. A total of 961 fulltime first year undergraduate students participated from various study programmes (Business and Economics, Geography, Teacher Education). The age of the participants was from 18 to 26 , and $56 \%$ were women. All the students graduated from high school and started their studies at the university. This means that they are representative of the high school graduates who successfully gained admission to university in the Czech Republic, Poland, and Slovakia in 2017. They represent the outputs of the secondary school education process in the context of society development, including ICT, in the mentioned countries. The sample of this cross-national study comprises 583 students from two Czech universities, 132 from one university in Slovakia, and 246 from one university in Poland (only complete questionnaires were used). The data were collected in October and November 2017.

\section{Data analysis}

The data analysis is done as follows. First, descriptive statistics were calculated to explore the actual use of ICT by first year university students with a focus on the use of ICT for leisure-time activities and on the use of social networks and mobile phones. Second, cluster analysis was used to was used to identify subgroups of students from the research sample (961 respondents from Czechia, Slovakia and Poland) having the same or similar measures of answers to the questionnaire items in order to assess their behaviour in relation to their ICT use.

The rho-Spearman test factor was used for measurements related to the identification of cooccurrence of indicators. In turn, a single-factor analysis of variance (ANOVA) was used to show the differences between the dependent and independent variables.

\section{Descriptive statistics}

\section{Results}

Tables $1 \mathrm{~A}-\mathrm{D}$ provide the descriptive statistics of the study sample. The data obtained refer to how the first year university students in our sample use ICT in their life.

Table $1 \mathrm{~A}$

\begin{tabular}{|c|c|c|c|c|c|c|c|}
\hline \multicolumn{5}{|l|}{ Use of ICT for leisure-time activities } & \multicolumn{3}{|c|}{ Percentage distribution } \\
\hline $\begin{array}{l}\text { How often do you use these activities in } \\
\text { your leisure-time? }\end{array}$ & Mean & $S D$ & Never & Rarely & $\begin{array}{l}\text { Some- } \\
\text { times }\end{array}$ & Often & Always \\
\hline Listening Internet radio & 2.6 & 1.2 & 21.4 & 30.4 & 24.2 & 16.9 & 7.1 \\
\hline Watching internet TV & 2.7 & 1.2 & 19.7 & 23.8 & 29.0 & 19.9 & 7.6 \\
\hline Playing games online & 2.3 & 1.2 & 30.3 & 34.0 & 19.6 & 8.6 & 7.5 \\
\hline Watching videos on Internet & 4.3 & 0.79 & 0.5 & 2.4 & 10.4 & 38.0 & 48.7 \\
\hline Using Internet banking & 4.0 & 1.2 & 7.9 & 5.9 & 12.0 & 29.7 & 44.5 \\
\hline Buying or ordering goods or services & 3.7 & 1.0 & 3.6 & 8.9 & 27.1 & 35.4 & 25.0 \\
\hline Selling online & 2.2 & 1.2 & 35.4 & 31.0 & 16.3 & 8.9 & 8.3 \\
\hline Searching information about travelling & 3.7 & 1.0 & 2.4 & 12.1 & 26.0 & 32.2 & 27.4 \\
\hline
\end{tabular}


Data on students' ICT use show that almost $87 \%$ of the students watch videos on Internet often or always and that $75 \%$ of them use Internet banking. On the other hand, they did not favour selling online or playing games online. There is a positive finding that $64 \%$ of the students did not prefer to spend their free time playing on-line games.

\section{Table 1 B}

Use of social networking (means, standard deviations, and percentage distribution, $n=961$ )

\begin{tabular}{|c|c|c|c|c|c|c|c|}
\hline \multirow{2}{*}{$\begin{array}{l}\text { Use of social networking } \\
\text { How often do you use Internet and } \\
\text { networks for following activities? }\end{array}$} & \multirow[b]{2}{*}{ Mean } & \multirow[b]{2}{*}{$S D$} & \multirow[b]{2}{*}{ Never } & \multirow[b]{2}{*}{ Rarely } & \multicolumn{3}{|c|}{ Percentage distribution } \\
\hline & & & & & $\begin{array}{l}\text { Some- } \\
\text { times }\end{array}$ & Often & Always \\
\hline Publishing messages on social networks & 2.7 & 1.1 & 17.0 & 28.7 & 29.4 & 16.3 & 8.5 \\
\hline Using Internet streaming & 1.6 & 0.90 & 63.9 & 22.9 & 8.3 & 3.2 & 1.7 \\
\hline $\begin{array}{l}\text { Creating and editing videos for social } \\
\text { networks }\end{array}$ & 1.9 & 1.0 & 49.4 & 27.4 & 15.0 & 4.0 & 4.3 \\
\hline Using a file sharing service with others & 2.7 & 1.2 & 19.3 & 28.2 & 28.0 & 15.9 & 8.6 \\
\hline $\begin{array}{l}\text { Participating as a member of a study } \\
\text { group on a social network }\end{array}$ & 3.7 & 1.2 & 8.4 & 9.2 & 18.5 & 28.6 & 35.3 \\
\hline Using social networks for communication ${ }^{\star}$ & 4.4 & 0.85 & 1.8 & 2.1 & 6.9 & 32.9 & 56.4 \\
\hline
\end{tabular}

Table $1 \mathrm{~B}$ shows that the most common purpose for which students use social networks is networking, and our research presents the positive finding that they use social networking for learning purposes (almost $64 \%$ of the students indicated that they often or always participate in study groups on social networks).

Table $1 \mathrm{C}$

Use of mobile phones (means, standard deviations, and percentage distribution, $n=961$ )

\begin{tabular}{lcccccccc}
\hline Use of mobile phones & \multicolumn{1}{l}{} & \multicolumn{6}{c}{ Percentage distribution } \\
\hline $\begin{array}{l}\text { How often do you use mobile phone } \\
\text { and for what activities? }\end{array}$ & Means & SD & Never & Rarely & Sometimes & Often & Always \\
\hline Using Internet on mobile phone & 4.5 & 0.93 & 2.7 & 3.5 & 4.3 & 18.9 & 70.6 \\
Sending e-mails from mobile & 3.8 & 1.2 & 7.9 & 9.7 & 15.9 & 23.5 & 43.0 \\
Sending photos from mobile & 4.1 & 1.0 & 2.6 & 6.5 & 14.2 & 28.4 & 48.4 \\
Using smartphone as a mobile hotspot & 2.8 & 1.5 & 31.5 & 16.6 & 16.1 & 13.2 & 22.5 \\
Working with tablet & 2.5 & 1.4 & 34.7 & 22.6 & 17.0 & 12.7 & 13.1 \\
Using cloud data synchronization & 2.4 & 1.5 & 43.9 & 14.4 & 13.6 & 9.2 & 18.9 \\
\hline
\end{tabular}

Table $1 \mathrm{C}$ also shows an interesting distribution of responses in some items. The highest mean and positive distribution is for the item Using Internet on mobile phone $(M=4.5, S D=0.9)$. It might be mentioned that $90 \%$ of students are already using smartphones. Conversely, more than half of the students do not prefer tablet work or mobile cloud use.

\section{Table $1 \mathrm{D}$}

Use of ICT for learning purposes (means, standard deviations, and percentage distributions, $n=961$ )

\begin{tabular}{|c|c|c|c|c|c|c|c|}
\hline \multirow{2}{*}{$\begin{array}{l}\text { Use of ICT for learning purposes } \\
\text { How often do you use computer and Internet } \\
\text { for learning activities? }\end{array}$} & \multirow[b]{2}{*}{ Means } & \multirow[b]{2}{*}{$S D$} & \multirow[b]{2}{*}{ Never } & \multirow[b]{2}{*}{ Rarely } & \multicolumn{3}{|c|}{ Percentage distribution } \\
\hline & & & & & $\begin{array}{l}\text { Some- } \\
\text { times }\end{array}$ & Often & Always \\
\hline Using Internet for learning purpose at home & 4.2 & 0.75 & 0.6 & 1.4 & 11.9 & 46.8 & 39.3 \\
\hline Studying school online courses & 2.2 & 1.2 & 42.7 & 19.0 & 20.0 & 12.4 & 5.9 \\
\hline $\begin{array}{l}\text { Searching relevant sources on Internet to meet } \\
\text { learning tasks }\end{array}$ & 3.7 & 0.96 & 2.3 & 8.4 & 27.8 & 41.1 & 20.4 \\
\hline $\begin{array}{l}\text { Using open e-learning courses (online courses) } \\
\text { (e.g. language, IT...) }\end{array}$ & 2.1 & 1.1 & 38.3 & 28.5 & 20.0 & 9.4 & 3.9 \\
\hline Using paid e-learning courses (online courses) & 1.3 & 0.73 & 81.6 & 11.9 & 3.6 & 1.7 & 1.2 \\
\hline
\end{tabular}


It is evident that many students also use the Internet at home for learning purposes $(86 \%)$, and more than $60 \%$ of them search for relevant resources for learning tasks. On the other hand, secondary school graduates do not prefer studying through online courses and probably $40 \%$ of them have no experience in this area. The number of students who use open and paid courses on the Internet for their further development is very low.

The following data were analysed using Statistica 12. First, groups of students from each country were analysed based on the findings for the four scales of students' ICT use for different purposes. The aim was to assess correlations among the selected variables of ICT use.

\section{Differences and similarities between the students from the Czech Republic, Slovakia, and Poland}

\section{Czech Republic}

Intensity and multidimensional character of phone use is connected statistically with learning with the use of new media, social media, free-time activities carried out through new media. It is interesting that this factor has no significant influence on a number of friends in SNS. Moreover, students who use social media more intensively, have slightly more friends on that service. However, from the pedagogical point of view, also important is a dependency determining that the students more often use Internet to learn (see Table 2.1).

\section{Table 2.1}

Relations between variables Czech Republic

\begin{tabular}{lcllll}
\hline & Age & FREE TIME & Education and ICT & Mobile devices & SNS \\
\hline FREE TIME & .088 & 1.000 & & & \\
Education and ICT & .086 & $.304^{\star \star}$ & 1.000 & & \\
Mobile devices & .005 & $.448^{\star \star}$ & $.170^{\star \star}$ & 1.000 & $.468^{\star \star}$ \\
SNS & .021 & $.406^{\star \star}$ & $.198^{\star \star}$ & .097 & 1.000 \\
Friends in Facebook & -.009 & .055 & -.070 & & $.152^{*}$ \\
\hline${ }^{* *} \mathrm{p}<0.001 ;{ }^{*} \mathrm{p}<0.01$ & & & &
\end{tabular}
(see Fig. 1).

Moreover, it should be stressed that the sex does not conditions any of the areas listed in any way

\section{Figure 1.}

Gender differences Czech Republic

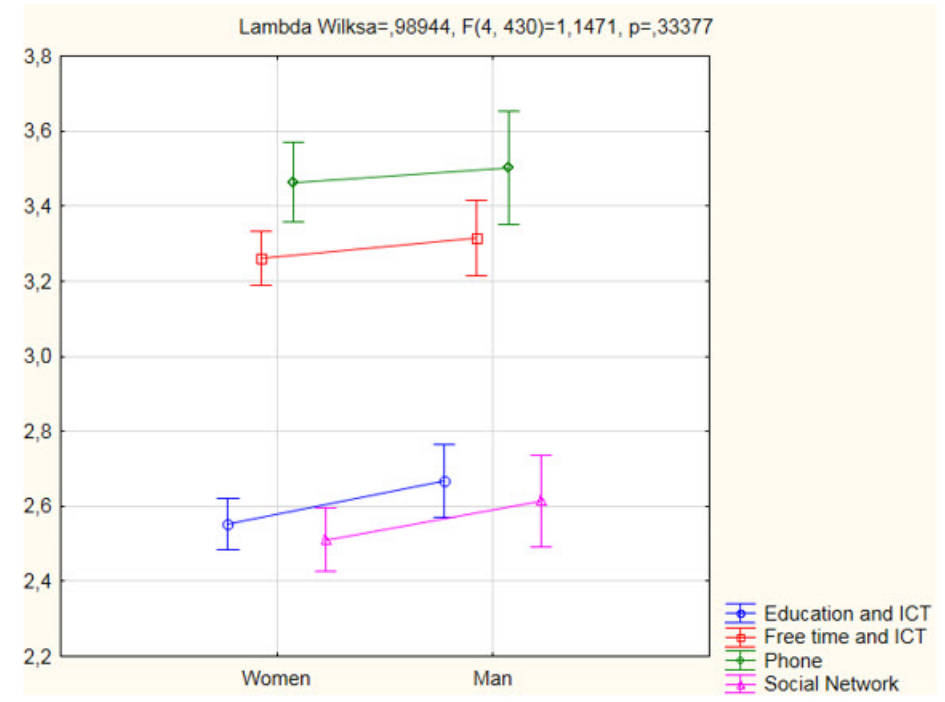

\section{Slovakia}

On the basis of analysis of dependencies concerning the influence of experiences connected with intensity of using ICT in free time and experiences connected with education indirectly through new media, or use of mobile phones, a conclusion may be drawn that these dependencies will be identical to 
the case of Czechia. The growth of intensity of ICT use in one of areas, conditions the activity in the next one. However, this does not apply to the number of friends collected in SNS, or to the age (see table 2.3)

\section{Table 2.3}

Correlation between variables Slovakia

\begin{tabular}{|c|c|c|c|c|c|}
\hline & Age & FREE TIME & Education and ICT & Mobile devices & SNS \\
\hline FREE TIME & -.050 & 1.000 & & & \\
\hline Education and ICT & -.048 & $.419^{\star \star}$ & 1.000 & & \\
\hline Mobile devices & -.004 & $.441^{\star \star}$ & $.244^{\star}$ & 1.000 & \\
\hline SNS & -.103 & $.412^{\star \star}$ & $.298^{\star *}$ & $.364^{* \star}$ & 1.000 \\
\hline Friends in Facebook & -.054 & .018 & .119 & .038 & $227^{*}$ \\
\hline
\end{tabular}

Similarly to CZ, persons that use all listed areas of SNS more intensively declare that Facebook is a nonfriendly environment for learning and teaching $F(4,130)=14.060, p=0.001$ ( $\eta^{2}$ partial $\left.=0.097\right)$. Analysis of a way to use media according to sexes presents significant similarities between CZ and SK. Thus, there are no statistical differences. The only variable, for which the difference is visible are experiences connected with using ICT for educational purposes. In this matter, female students are slightly more experienced than male students $F(1,130)=8.264, p=0.004$ ( $\left.\eta^{2} p a r t i a l=0.059\right)$ (see Fig. 2).

\section{Figure 2.}

Gender differences Slovakia

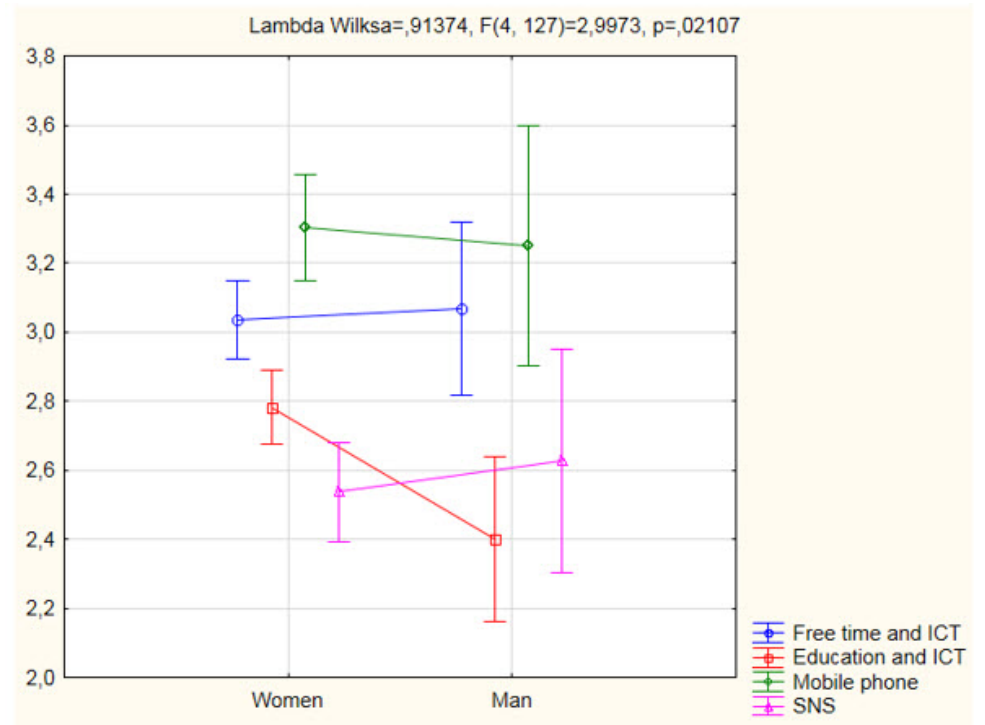

\section{Poland}

Poland is not different in any way in the matter of dependencies between particular activities conditioned by ICT. Similarly to CZ and SK, the variety of applications of mobile phones, other mobile devices and SNS increases along with growing activity in learning. Unlike other countries with decreasing age, the number of friends in SNS also decreases (see table 2.5).

\section{Table 2.5}

Correlations between variables Poland

\begin{tabular}{lccccc}
\hline & Age & FREE TIME & Education and ICT & Mobile devices & SNS \\
\hline FREE TIME & $.207^{\star \star *}$ & 1.000 & & & \\
Education and ICT & $.2832^{\star \star}$ & $.549^{\star \star}$ & 1.000 & & \\
Mobile devices & .057 & $.538^{\star \star}$ & $.425^{\star \star}$ & 1.000 & \\
SNS & $.125^{\star \star}$ & $.422^{\star \star}$ & $.458^{\star \star}$ & $.483^{\star \star}$ & 1.000 \\
Friends in Facebook & -.039 & .056 & .084 & .040 & .078 \\
\hline
\end{tabular}

${ }^{* *} p<0.001 ;{ }^{*} p<0.01$ 
Males use SNS and other educational resources in the network more intensively than females, however, it is not a statistically-noticeable difference. According to ways to use phones and other mobile devices, there were no differences observed. However, among the group of Polish students, males use digital resources to plan free time more often than male students $F(1,327)=4.794, p=0.029$ ( $\eta^{2}$ partial $=$ 0.014) (see Fig. 3).

Figure 3.

Gender differences Poland

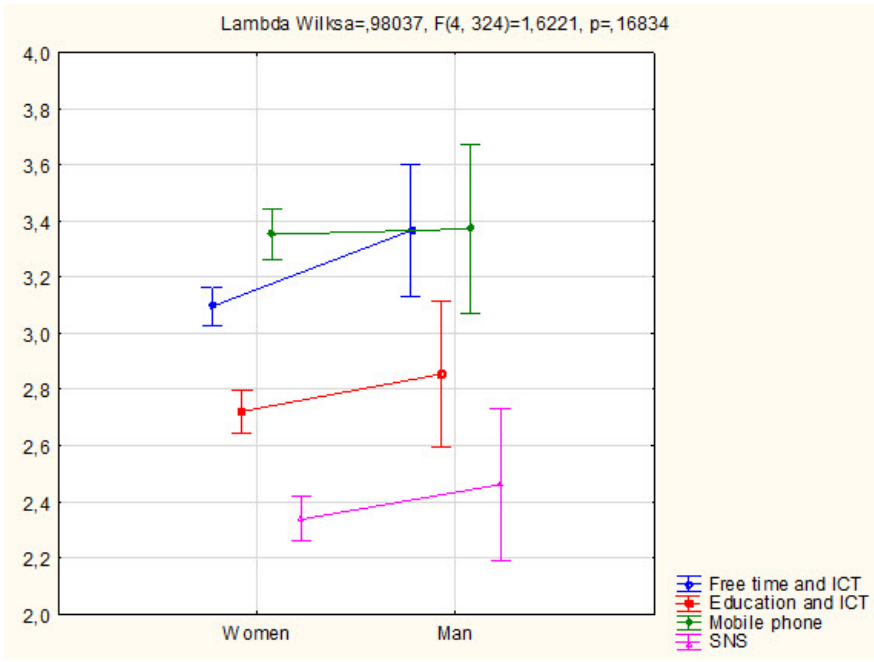

\section{Differences and similarities between Czechia, Slovakia and Poland}

The countries listed are characterized by equal tendencies in the matter of intensity of using ICT in education and mobile devices, and SNS. Along with an increase in intensity in one area, the activity in another also increases. Moreover, according to the analysis of multilinear regression model, the common key factor for educational experiences indirectly through electronic media is a way to incorporate ICT in free time. Students who use streaming channels, play online, sell and purchase online, use online banking systems or search for matters concerning travelling are experiences in the matter of education indirectly through ICT. The factor of digital competence and their use in free time, plays a significant role in creating educational spaces (see Fig. 4).

\section{Figure 4.}

Differences between Czech Republic, Slovakia and Poland

Lambda Wilks $=, 92270, F(8,1782)=9,1425, p=, 00000$

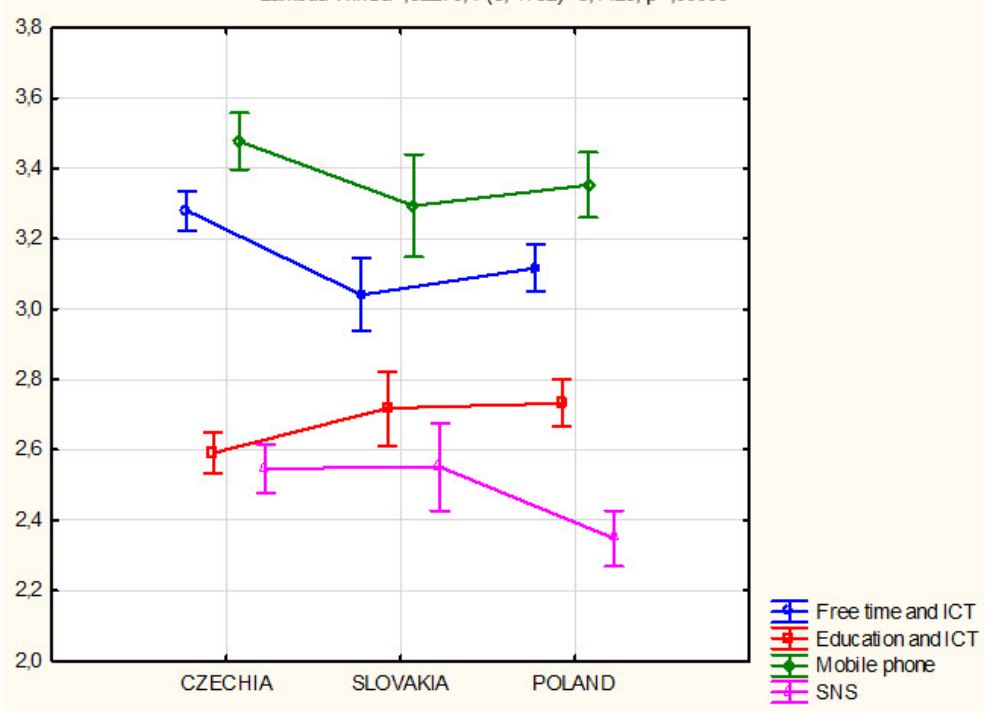

Considering the use of ICT in free time, the most active students are Czechs, and the least active are Slovakians. The difference is significant $F(2,894)=11.072, p=0.000\left(\eta^{2}\right.$ partial $\left.=0.024\right)$. There were no 
significant statistical differences between Poland and Slovakia in the process of learning through ICT, and Czechs students are slightly less experienced $F(2,894)=5.5525, p=0.004\left(\eta^{2}\right.$ partial $\left.=0.012\right)$. However, these differences are not very visible or important in the matter of educational processes. The most active users of mobile phones are students from Czechia, however, between PL and SK, there is a slight difference $F(2,894)=3.247, p=0.039$. Students from SK and CZ use SNS most intensively in comparison with $P L$ group, that is ranked slightly lower $F(2,659)=6.649, p=0.001$ ( $\eta^{2}$ partial $=0.007$ ).

The difference intensity of use of SNS presented is statistically significant $F(2,893)=40.702$, $p=0.000\left(\eta^{2}\right.$ partial $\left.=0.017\right)($ see Table 3$)$.

\section{Table 3}

Numbers of friends on social networks by student group

\begin{tabular}{lcccccc}
\hline Country & N Friends in Facebook & Friends in Facebook Friends in Facebook Friends in Facebook & Friends in \\
& & AVG & Std. Dev. & Std. Err & $-95,00 \%$ & $\begin{array}{c}\text { Facebook } \\
+95,00 \%\end{array}$ \\
\hline & 896 & 442.747 & 473.826 & 15.829 & 411.680 & 473.814 \\
CZ & 329 & 622.307 & 506.588 & 27.929 & 567.364 & 677.250 \\
SK & 435 & 334.966 & 352.280 & 16.891 & 301.768 & 368.163 \\
PL & 132 & 350.394 & 593.317 & 51.642 & 248.235 & 452.553 \\
\hline
\end{tabular}

Also, the difference in perception of Facebook as a tool for learning by group of students is also visible $F(2,894)=24.058, p=0.000\left(\eta^{2}\right.$ partial $\left.=0.051\right)$. Students from PL have the most positive attitude towards the assumption that the environment of a popular social media may be attractive an efficient learning environment.

\section{First year university students and ICT user subgroups analysis}

\section{Research assumption}

The distribution of the results of student answers from the three selected countries about the use of ICT in learning and leisure can be clarified by means of five groups of factors.

The aim of this part of the study was to identify specific groups of students in the sample who have the same or closely resembling measure of response to each item in the questionnaire. Therefore, we have described their features using cluster analysis (Everitt, 2011). The cluster analysis used the results of studies on the use of ICT in leisure time, SNS, use of mobile phones and the use of ICT for research purposes, and identified homogeneous groups among first-year students in terms of ICT use.

\section{Figure 5.}

Cluster analysis: Groups of students according to their use of ICT

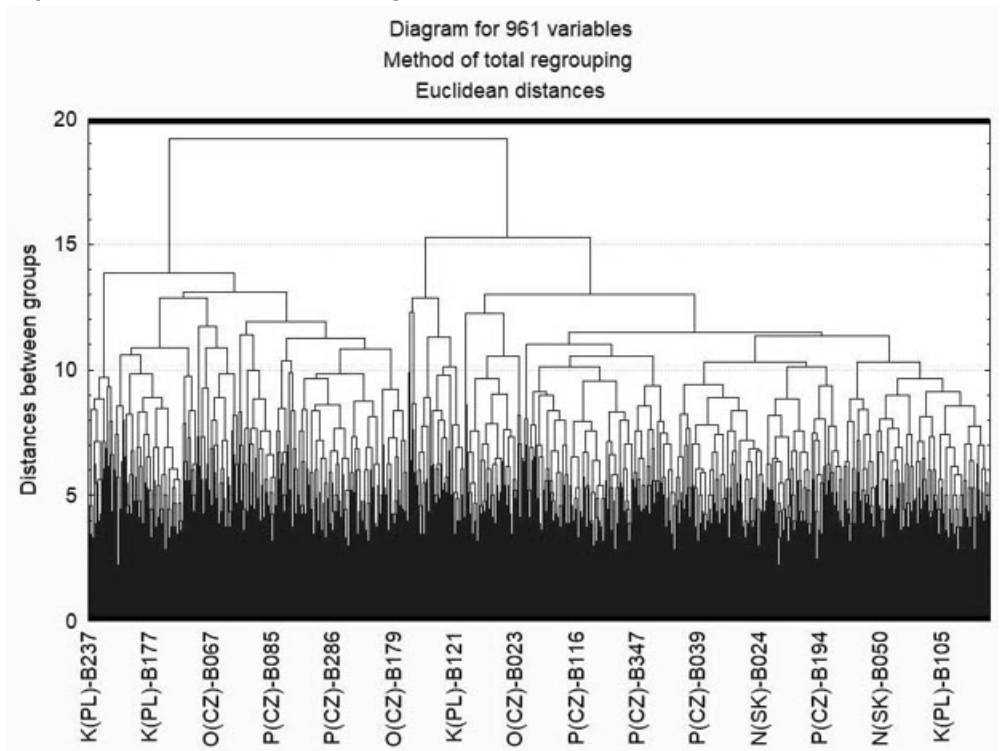


The hierarchical clustering procedure allows a comprehensive and detailed analysis of the structure of the dataset. The distance matrix clearly indicates the similarity of individual objects or clusters. It can be seen from Figure 6 above that the students from these three countries could be divided according to the similarity of their answers to individual questionnaire items into five independent groups (a detailed description is provided in Table 5).

To show with "certainty that there is no student subgroup that explicitly rejects all activities associated with the use of ICT, the k-means clustering technique was used to identify subgroups of students" (Eger et al, 2018, Scherer et al., 2017).

\section{Figure 6.}

Cluster analysis of the assessment of the students according their ICT use

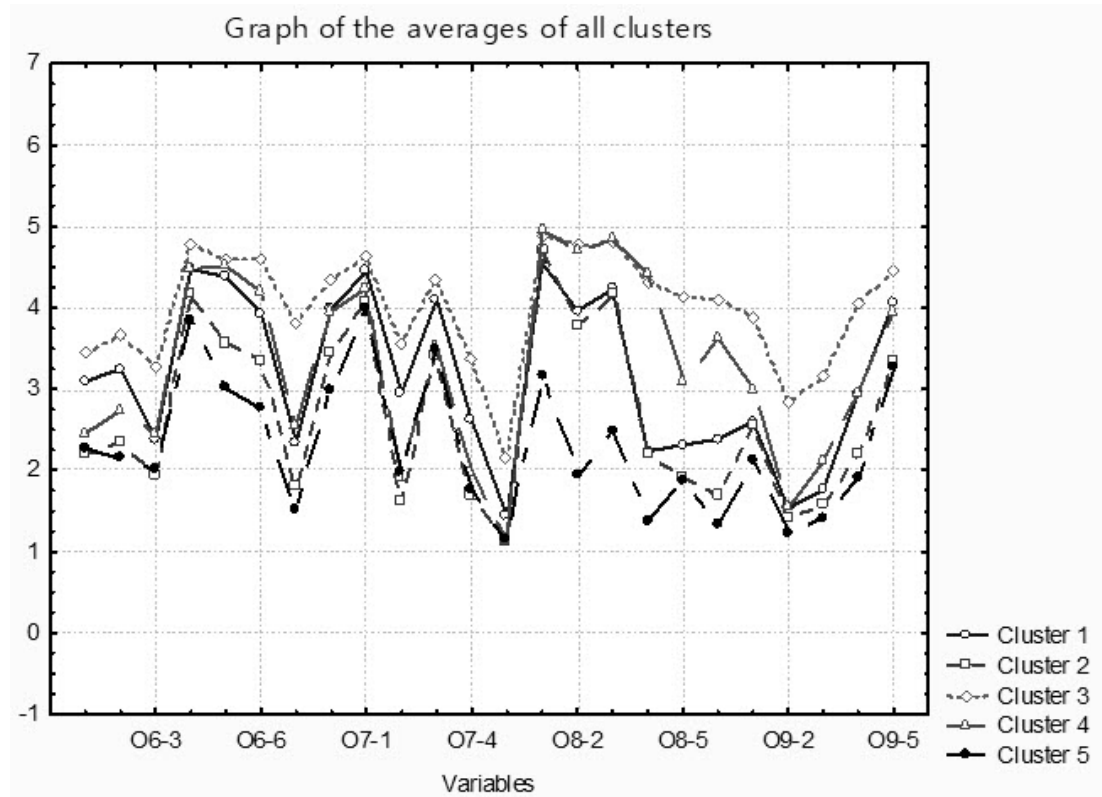

As shown in Figure 6, this assumption has been validated. The respondents, first year students from the Czech Republic, Slovakia and Poland, can be grouped into five relatively separate groups according to their own preferences. For greater comprehensiveness of the analysis these groups were described and the number of students in each of them was determined. An overview of the number of respondents belonging to the five groups is presented in Table 4.

\section{Table 4}

Number of respondents in each group according to the similarities of the questionnaire item evaluations

\begin{tabular}{lcccccc}
\hline \multicolumn{7}{c}{ Respondents $n=961$} \\
& Cluster 1 & Cluster 2 & Cluster 3 & Cluster 4 & Cluster 5 & Total \\
\hline Count & 208 & 293 & 85 & 226 & 149 & 961 \\
Count in \% & 21.64 & 30.49 & 8.84 & 23.52 & 15.50 & 100 \\
\hline
\end{tabular}

Each group has a different intensity of the measured characteristics. This means that each group uses digital media in a different way. Some elements in particular groups may have similar intensities, but do not have the same usage styles in each area. Detailed characteristics are presented in Table 5. 


\section{Table 5}

Characteristic behaviours of subgroups of students

\begin{tabular}{|c|c|c|}
\hline $\begin{array}{l}\text { Groups of } \\
\text { students }\end{array}$ & Characteristic behaviour & Overall group characteristic \\
\hline $\begin{array}{l}1 \text { - 'Mobile } \\
\text { subgroup' }\end{array}$ & $\begin{array}{l}\text { Students use ICTs for: } \\
\text { - using Internet on their mobile } \\
\text { - sending/receiving messages from } \\
\text { mobile } \\
\text { - } \text { sending photos from mobile } \\
\text { - } \text { cloud data synchronization }\end{array}$ & $\begin{array}{l}\text { This subgroup of students } \\
\text { prefers the use of mobile } \\
\text { devices to perform different } \\
\text { activities related to the general } \\
\text { application of ICT in their life } \\
\text { without a clear intention to } \\
\text { learn with these technologies. }\end{array}$ \\
\hline $\begin{array}{l}2- \\
\text { 'Educational } \\
\text { subgroup' }\end{array}$ & $\begin{array}{l}\text { Students use ICTs for: } \\
\text { - Internet at home for learning purposes } \\
\text { - learning school online courses } \\
\text { searching relevant sources on the } \\
\text { - Internet to meet learning tasks } \\
\text { doing open online courses (IT, } \\
\text { languages, etc.) } \\
\text { - doing paid online courses }\end{array}$ & $\begin{array}{l}\text { The subgroup of students uses } \\
\text { ICT to fulfil learning activities at } \\
\text { school, and they also use ICT } \\
\text { in their informal education as a } \\
\text { tool for further learning. }\end{array}$ \\
\hline $\begin{array}{l}3 \text { - 'Social } \\
\text { subgroup' }\end{array}$ & $\begin{array}{l}\text { Students use ICTs for: } \\
\text { - posting messages to social networking } \\
\text { sites } \\
\text { - using Internet streaming } \\
\text { - creating and uploading self-created } \\
\text { - videos to social websites to be shared } \\
\text { - using a file sharing service with others }\end{array}$ & $\begin{array}{l}\text { The subgroup of students } \\
\text { clearly prefers the use of social } \\
\text { networks to develop social } \\
\text { contacts and to make self- } \\
\text { presentation. }\end{array}$ \\
\hline $\begin{array}{l}4 \text { - 'Network } \\
\text { subgroup' }\end{array}$ & $\begin{array}{l}\text { Students use ICTs for: } \\
\text { - Internet banking } \\
\text { - buying or ordering goods or services } \\
\text { - } \text { selling online } \\
\text { finding information about travel }\end{array}$ & $\begin{array}{l}\text { The subgroup of students } \\
\text { prefers the use of ICT to a } \\
\text { general orientation in society, } \\
\text { not distinguishing between } \\
\text { using ICT for learning activities } \\
\text { at school as well as in their } \\
\text { informal education or for } \\
\text { entertainment. }\end{array}$ \\
\hline $\begin{array}{l}5- \\
\text { 'Entertainment } \\
\text { subgroup' }\end{array}$ & $\begin{array}{l}\text { Students use ICTs for: } \\
\text { - listening Internet radio } \\
\text { - } \text { watching internet TV } \\
\text { - } \text { playing games online } \\
\text { watching videos on Internet (YouTube, } \\
\text { social networks. news...) }\end{array}$ & $\begin{array}{l}\text { The subgroup of students uses } \\
\text { ICT primarily for entertainment, } \\
\text { with no apparent use for } \\
\text { learning purpose or making } \\
\text { social contacts. }\end{array}$ \\
\hline
\end{tabular}

\section{Discussion}

This research was aimed at examining how students integrate SNS and new mobile devices (smartphones) into their learning, thereby providing them with informal learning contexts and encouraging their orientation to almost immediate communication and collaboration. A second aim was to provide a better understanding of how first year university students really use ICT in their life for school and leisuretime-activity-related tasks. In the following we discuss our findings with respect to the three hypotheses.

The first hypothesis on the use of mobiles and social networks among groups of first year university students from the Czech Republic, Slovakia, and Poland was examined using descriptive statistics. The findings show that students who use streaming channels, play online, sell and purchase online, use online banking systems, or search online about travelling are also experienced in applications of ICT for learning purposes.

We can state that the use of ICT in students' leisure-time activities plays a significant role in creating learning environment. This finding is in line with results by Rothagi et al., (2016) that also stress important role of the use of ICT in recreation activities.

The second hypothesis assumes that ICT use and the level of ICT self-efficacy by first year 
university students is positively related to their use of ICT for learning purpose. We found the following results for the groups from the three countries. There is a slightly positive dependency between use of social networks and mobile devices and ICT use for learning purpose.

Our cluster analysis found five different subgroups of ICT users. We can associate the characteristics of only two subgroups with the use of ICT for learning purposes ('educational subgroup', 'network subgroup'). On this point, this study has generated new knowledge about the relations between application of social networks and mobile phones by university students and the use of ICT for learning purpose. This fills a gap in ICILS (Fraillon et al., 2015) that did not focus on the use of social networks and mobile phones by students.

Overall, the cluster analysis of the data supported the third hypothesis, that first year university students do not constitute a homogenous group of young people in their use of ICT in their daily lives. On the basis of the analysis it is possible to describe the characteristic behaviour of individual subgroups of students regarding their use of ICT for leisure-time activities and learning purposes. We identified five subgroups of students in the use of ICT: The 'mobile subgroup', who prefer to use mobile devices; the 'educational subgroup' of participants focused on the use of ICT for learning purposes; the 'social subgroup', with an orientation towards publishing, messaging, and sharing on social media; the 'network subgroup' which predominantly applies the Internet to internet banking, e-commerce, and searching for relevant information, e.g. for travelling; and the 'entertainment subgroup' of participants who use ICT primarily for entertainment without an emphasis on learning or social contacts. Thus, our results show strong variations in ICT competence and its applications in students' lives. This finding is in line with the results of Hatlevik et al., (2015), Rohatgi et al., (2016), and Siddiq et al., (2017).

\section{Conclusions and further research}

The research provides an overview of selected areas of the ICT literacy of first year university students from three countries in and out of the university environment. Our results indicate that students who use ICT intensively for leisure-related tasks are also experienced in the matter of ICT applications for learning purpose. Learning with ICT is conditioned by the use of new technologies in other areas. Intense ICT use in leisure time is a dominant predictor of self-efficacy among students in the application of ICT for learning purpose. Students who use social networks intensively also find social networking a positive way to learn. The use of mobile devices to connect to the Internet is growing. Results show that $90 \%$ of the students are already using smartphones. On the other hand, first year university students (graduates of secondary schools) do not prefer studying via school online courses and roughly $40 \%$ of them have no experience in this area. Men use social networking intensively than women, though the difference is not statistically significant.

Our results showed that university students are not a homogenous group of new media users, and further suggest that the effectiveness of ICT use at university and at home depends on the current practices for which students use it and, on their ability, to integrate digital tools into their learning process and their everyday lives. The following five subgroups of students in the use of ICT were identified: the mobile subgroup, the educational subgroup, the network subgroup, the social subgroup, and the entertainment subgroup. Educators should be aware of the differences between these five user groups and take them into account when planning, including, and evaluating the educational process. The different levels of ICT competence of university students will influence their learning performance, future employment, further education, and leisure-time activities.

Also, Hatlevik et al., (2018) indicate that "ICT self-efficacy is positively related to computer and information literacy when controlled for other student characteristics and background contextual variables". For example, findings by Wakefield and Frawley (2020) "suggest the use of SNS to support learning needs to be done in a way that carefully considers how and why students engage with this part of ICT". The presented study highlights the place of social networks and mobile phones in this issue, but also draws attention to the context of three selected countries.

\section{Theoretical and practical implications}

Our discoveries are important for both scientists and professionals, because little is known about the subgroups of students differing in how they use ICT in practice. Many researchers have examined the ICT competence of young people. During the past few years, studies have been conducted primarily to investigate ICT competence focusing on software applications or on the results of teaching and learning process (e.g. Fraillon et al., 2015; Rosman and Burita, 2014). We believe that our research conveys 
important insights and presents potentially important findings related to the ICT competence of young people having a strong focus on social media and mobile use in their everyday lives.

Our results may serve as a foundation for the pedagogical application of ICT use in the teaching and learning process. It is especially important to distinguish the subgroups of students in their ICT usage. The findings provide evidence that an increase of ICT competence in one area usually influences the ability to use ICT for learning purposes as well. This study recommends that educators pay attention to how their students really use ICT in their leisure-time activities.

\section{Limitations and further directions of research}

Some limitations of the conducted research have to be considered. First, we applied the approach of Rohatgi et al., (2016), holding that ICT literacy and computer and information literacy are slightly different conceptualizations of competence in ICT, and used these terms interchangeably. Second, our findings are based on a questionnaire given to first year university students from three selected countries. In fact, it is possible that national or regional conditions in other countries would slightly change the subgroups of ICT users identified in this study. We recognize that the university setting may not be generalizable to the full population. Third, the "measurement of students' ICT-related interest and enjoyment" (Scherer et al., 2017) was not implemented in our research.

Future research can be improved by increasing the size of the sample pool and by expanding it to other countries. Future research can extend the items of our scales in accordance with the development of technology and changes in students' behaviour, especially in the use of SNS and mobile devices.

\section{Acknowledgements}

We would like to thank all those who have contributed to this text, i.e. the surveyors, students and the authorities of the home research units: West Bohemia University, Pedagogical University of Cracow, Palacky University and Constantine the Philosopher University in Nitra.

\section{Conflict of interests}

The authors declare no conflict of interest.

\section{References}

Aesaert, K., Voogt, J., Kuiper, E., \& van Braak, J. (2017). Accuracy and bias of ICT self-efficacy: An empirical study into student's ever- and underestimation of their ICT competencies. Computers in Human Behavior, 75, 92-102. https://doi. org/10.1016/j.chb.2017.05.010.

Ajjan, H., \& Hartshorne, R. (2008). Investigating faculty decisions to adopt Web 2.0 technologies: theory and empirical tests. The Internet and Higher Education, 11(2), 71-80. https://doi.org/10.1016/j.iheduc.2008.05.002.

Ali, M., Jacob, R. A. I. B. R., Endut, B. N. A-A, B., \& Langove, N. U. (2017). Strengthening the academic usage of social media: An exploratory study. Journal of King Saud University - Computer and Information Sciences, 29(4), 553-561. https:// doi.org/10.1016/j.jksuci.2016.10.002.

Areepattamannil, S., Santos, I. M. (2020). Adolescent students' perceived information and communication technology (ICT) competence and autonomy: Examining links to dispositions toward science in 42 countries. Computers in Human Behavior, 89, 50-58. https://doi.org/10.1016/j.chb.2019.04.005

Arteaga, M., Tomczyk, Ł., Barros, G., Sunday Oyelere, S. (2020). ICT and education in the perspective of experts from business, government, academia and NGOs: in Europe, Latin America and Caribbean. Ecuador: Universidad del Azuay.

Bandura, A. (1986). Social foundation of thought and action: A social cognitive theory. Englewood Cliffs, NJ: Prentice-Hall.

Bandura, A. (1996). Multifaced impact of self-efficacy beliefs on academic functioning. Child Development. 67(3), $1206-1222$. http://www.jstor.org/stable/1131888.

Benes, P., Mudrak, D., Prochazka, J., Rambousek, V., \& Stipek, J. (2008). Research of ICT education in the Czech Republic. Problems of Education in the $21^{\text {st }}$ century, 5, 24-34.

Chou, CH-H., \& Pi, S-M. (2015) The Effectiveness of Facebook Groups for e-Learning. International Journal of Information and Education Technology, 5(7), 477-482.

DESI (2020). The Digital Economy and Society Index. Retrieved April 2020 from: https://ec.europa.eu/digital-single-market/ en/desi

Digital (2020). Global digital overview. Retrieved March 2020 from: https://wearesocial.com/digital-2020/

Education and Training Monitor (2017). Country reports. Retrieved January 2018 from: http://ec.europa.eu/education/policy/ strategic-framework/et-monitor/country-reports_en

Eger, L., \& Egerová, D. (2013). e-Learning trends in Central Europe: The case of the Czech Republic, Knowledge Management \& E-Learning, 5(3), 375-387. https://doi.org/10.34105/j.kmel.2013.05.027

Eger, L., Egerová, D., Mičík, M., Varga, E., Czeglédi, C., Tomczyk, L., Sládkayová, M. (2020). Trust building and fake news on social media from the perspective of university students from four Visegrad countries. Communication Today, 11(1), 70-88. Retrieved from: https://search.proquest.com/openview/3eb7b580383300bd001ab76e8aa405af/1?pq- 
Eger, L., et al. (2020). How do first year university students use ICT in their leisure time and for learning purposes?, International Journal of Cognitive Research in Science, Engineering and Education (IJCRSEE), 8(2), 35-52

origsite $=$ gscholar $\& \mathrm{cbl}=1606370$

Eger, L., Klement, M., Tomczyk, L., Pisoňová, M., \& Petrová, G. (2018). Different user groups of University students and their ICT competence: Evidence from three countries in Central Europe. Journal of Baltic Science Education, 17(5), 851866. Retrieved from: http://www.scientiasocialis.It/jbse/files/pdf/vol17/851-866.Eger_JBSE_Vol.17_No.5.pdf

EUROSTAT (2020). Digital skills. Retrieved January 2020 from: http://ec.europa.eu/eurostat/data/database

Flanigan, A. E., \& Babchuk, W. A. (2015). Social media as academic quicksand: A phenomenological study of student experiences in and out of the classroom. Learning and Individual Differences, 44, 40-45. https://doi.org/10.1016/j. lindif.2015.11.003.

Fraillon, J., Schulz, W., Friedman, T., Ainley, J., \& Gebhardt, E. (2015). International Computer and Information Literacy Study: ICILS 2013: Technical Report. Retrieved September 2015 from: http://iave.pt/images/FicheirosPDF/Estudos_ Internacionais/ICILS/ICILS_2013_Technical_Report.pdf

Forouzesh, M., \& Darvish, M. (2012). Characteristics of Learning Management System (LMS) and Its Role in Education of Electronics. In Conference proceedings of eLearning and Software for Education, eLSE, No. 01, pp 495-500, Universitatea Nationala de Aparare Carol I.

Gikas, J., \& Grant, M. M. (2013). Mobile computing devices in higher education: Student perspectives on learning with cellphones, smartphones \& social media. The Internet and Higher Education, 19(1), 18-26. https://doi.org/10.1016/j. iheduc.2013.06.002.

Goldsmith-Pinkham, P. \& Imbens, G, W. (2013). Social Networks and the Identification of Peer Effects. Journal of Business \& Economic Statistics, 31(3), 253-264. https://doi.org/10.1080/07350015.2013.801251.

Goodfellow, R. (2011). Literacy, literacies and the digital in higher education. Teaching in Higher Education, 16(1), 131-144. https://doi.org/10.1080/13562517.2011.544125.

Gaudreau, P, Miranda, D., \& Gareau, A. (2014). Canadian university students in wireless classrooms: What do they do on their laptops and does it really matter? Computers \& Education, 70, 245-255. https://doi.org/10.1016/j.compedu.2013.08.019.

Hatlevik, O. E., Gudmundsdóttir, G. B., \& Loi, M. (2015). Digital diversity among upper secondary students: A multilevel analysis of the relationship between cultural capital, self-efficacy, strategic use of information and digital competence. Computers \& Education, 81, 345-353. https://doi.org/10.1016/j.compedu.2014.10.019.

Hatlevik, O. E., Throdsen, I., Massimo, L., \& Gudmundsdóttir, G. B. (2018). Students' ICT self-efficacy and computer and information literacy: Determinants and relationships. Computers \& Education, 118, 107-119. https://doi.org/10.1016/j. compedu.2017.11.011

Hrtoňová, N., Kohout, J., Rohlíková, L., \& Zounek, J. (2015). Factors influencing acceptance of e-learning by teachers in the Czech Republic. Computers in Human Behavior, 51, 873-879. https://doi.org/10.1016/j.chb.2014.11.018.

Harris, P. (2015). Student Mobile Device Survey 2015. National Report: College Students. Pearson. Retrieved May 2017 from: https://www.pearsoned.com/wp-content/uploads/2015-Pearson-Student-Mobile-Device-Survey-College.pdf

ICT Development Index 2017. ITUdata. Retrieved Juni 2018 from: http://www.itu.int/net4/ITU-D/idi/2017/index.html

ICT@Europe.edu: Information and Communication Technology in European Education Systems, (2001).EURYDICE Retrieved May 2017 from: http://www.sel-gipes.com/uploads/1/2/3/3/12332890/2001_eurydice_-_icteurope.edu.pdf

Juhaňák, L., Zounek, J., Záleská, K., Bárta, O., Vlčková, K. (2019). The relationship between the age at first computer use and students' perceived competence and autonomy in ICT usage: A mediation analysis. Computers \& Education, 141, 103614. https://doi.org/10.1016/j.compedu.2019.103614

Junco, R. (2012). The relationship between frequency of Facebook use, participation in Facebook activities, and student engagement. Computers \& Education, 58(1), 162-171. https://doi.org/10.1016/j.compedu.2011.08.004.

Kiss, G. (2017). Measuring the ICT competencies in Slovakia and in Serbia in the higher education. SHS Web Conferences, 37, 01075, https://doi.org/10.1051/shsconf/20173701075.

Kim, Ch., \& Yang, S-U. (2017). Like, comment, and share on Facebook: How each behavior differs from the other. Public Relations Review, 43(2), 441-449. https://doi.org/10.1016/j.pubrev.2017.02.006.

Klement, M. (2013). E-learning through the eyes of the Czech students (Aprendizaje electrónico desde el punto de vista de los estudiantes universitarios). Journal of Science Education, 14(2), 66-70.

Klement, M. (2017). Which ICT Tools Are Used By Teachers Most Often In Their Work? 8th ICEEPSY The International Conference on Education and Educational Psychology. The European Proceedings of Social \& Behavioural Sciences. 252-263. http://dx.doi.org/10.15405/epsbs.2017.10.24.

Lau, W, W. F. (2017). Effects of social media usage and social media multitasking on the academic performance of university students. Computers in Human Behavior, 68, 286-291. https://doi.org/10.1016/j.chb.2016.11.043.

Lee, L., Chen, D-T., \& Lin, T-B. (2015). Understanding new media literacy: The development of a measuring instrument. Computers \& Education, 85, 84-93. https://doi.org/10.1016/j.compedu.2015.02.006.

Machková, H. (2016). Higher education in Central Europe and its impact on countries' competitiveness. Central European Business Review, 5(1), 62-68.

Marino, C., Finos, L., Vieno, A., Lenzi, M., \& Spada, M. M. (2017). Objective Facebook behaviour: Differences between problematic and non-problematic users. Computers in Human Behavior, 73, 541-546. https://doi.org/10.1016/j. chb.2017.04.015.

Mazman, S. G., \& Usluel, Y. K. (2010). Modeling educational usage of Facebook. Computers \& Education, 55(2), 444-453. https://doi.org/10.1016/j.compedu.2010.02.008.

Measuring Digital Skills across the EU: EU wide indicators of Digital Competence. (2014) Retrieved May 2017 from: https:// ec.europa.eu/digital-single-market/en/news/measuring-digital-skills-across-eu-eu-wide-indicators-digital-competence

Nunnally, J., \& Bernstein, L. (1994). Psychometric Theory, New York: McGraw-Hill Higher Inc.

OECD (2017). Education at a Glance 2017: OECD Indicators, OECD Publishing, Paris. http://dx.doi.org/10.1787/eag-2017-en

Qureshi, I. A., Raza, H., \& Whitty, M. (2015). Facebook as e-learning tool for higher education institutes. Knowledge Management \& E-Learning: An International Journal (KM\&EL),6(4), 440-448. Retrieved December 2015 from: http:// www.kmel-journal.org/ojs/index.php/online-publication/index

Pagastergiou, M. (2010). Enhancing physical education and sports science students' self-efficacy and attributes regarding information and communication technologies through computer literacy course. Computers \& Education, 54(1), 298- 
Eger, L., et al. (2020). How do first year university students use ICT in their leisure time and for learning purposes?, International Journal of Cognitive Research in Science, Engineering and Education (IJCRSEE), 8(2), 35-52

308. https://doi.org/10.1016/..compedu.2009.08.015.

Pascarella, E. T., \& Terenzini, P. T. (2005). How college affects students: A third decade of research. San Francisco, JosseyBass.

Picatoste, J., Pérez-Ortiz, L., \& Ruesga-Benito, S. (2018). A new educational pattern in response to new technologies and sutainble development. Enlightening ICT skills for youth employability in Eurepean Union. Telematics and Informatics, 35(4), 1031-1038. https://doi.org/10.1016/j.tele.2017.09.014.

Plebańska, M. (2017). Polska szkoła w dobie cyfryzacji [Polish school in the age of digitization]. Warszawa: Uniwersytet Warszawski. PCG Edukacja.

Potyrała, K. (2017). iEdukacja. Synergia nowych mediów i dydaktyki [iEdukacja. Synergy of new media and didactics.]. Kraków: Wydawnictwo Uniwersytetu Pedagogicznego.

Půžová, K., Marešová, P. (2014). Czech Republic's Competitiveness in ICT Market. Procedia - Social and Behavioral Sciences, 10, 880-885. https://doi.org/10.1016/j.sbspro.2013.12.558

Rosman, P., \& Burrita, L. (2014). Concept of the computer science course and some aspects of ICT integration into education. E\&M Economics and Management, 17(3), 169-180. http://dx.doi.org/10.15240/tul/001/2014-3-013

Rothagi, A., Scherer, R., \& Hatlevik, O. E. (2016). The role of ICT selfefficacy for students' ICT use and their achievement in a computer and information literacy test. Computers \& Education, 102, 103-116. https://doi.org/10.1016/j. compedu.2016.08.001.

Salomon, A., \& Kolikant, Y, B-D. (2016). High-school students'perceptions of the effects of non-academic usage of ICT on their academic achievements. Computers in Human Behavior, 64, 143-151. https://doi.org/10.1016/j.chb.2016.06.024.

Scherer, R., Rohatgi, A., \& Hatlevik, O. E. (2017). Students' profiles of ICT use: Identification, determinants, and relations to achievement in a computer and information literacy test. Computers in Human Behavior, 70, 486-499. https://doi. org/10.1016/j.chb.2017.01.034.

Selwyn, N. (2007). Screw blackboard. Do it on Facebook! An investigation of students' educational use of Facebook. [Electronic Version]. Retrieved May 2017 from: https://www.scribd.com/doc/513958/Facebook-seminar-paper-Selwyn

Slechtová, P. (2015). Attitudes of undergraduate students to the use of ICT in education. Procedia - Social and Behavioral Sciences, 171, 1128 - 1134. https://doi.org/10.1016/j.sbspro.2015.01.218.

Statista, (2018). Number of social media users worldwide from 2010 to 2021 (in billions) Retrieved May 2018 from: https://www. statista.com/statistics/278414/number-of-worldwide-social-network-users/

Siddiq, F., Cochyyev, P., \& Willson, M. (2017). Learning in Digital Networks - ICT literacy: A novel assessment os students' 21st century skills. Computers \& Education, 109, 11-37. https://doi.org/10.1016/j.compedu.2017.01.014

Stošić, L., \& Stošić, I. (2015). Perceptions of teachers regarding the implementation of the internet in education. Computers in Human Behavior, 53, 462-468. https://doi.org/10.1016/j.chb.2015.07.027

Stout, D. (2020). Social Media Statistics 2020: Top Networks by the Numbers (2020). Retrieved March 2020 from: https:// dustinstout.com/social-media-statistics/

Sung, Y-T., Chang, K-E., \& Liu, T-Ch. (2016). The effects of integrating mobile devices with teaching and learning on students' learning performance: A meta-analysis and research synthesis. Computers \& Education, 94, 252-275. https://doi. org/10.1016/j.compedu.2015.11.008.

Tezer, M., Yildiz, E. P., \& Uzunboylu, H. (2018). Online authentic learning self-efficacy: a scale development. Quality \& Quantity, 52(1), 639-649. https://doi.org/10.1007/s11135-017-0641-1.

Tomczyk, L., \& Kopecký, K. (2016). Children and Youth Safety on Internet: Experiences from Czech Republic and Poland. Telematics and Informatics, 33(3), 822-833. https://doi.org/10.1016/j.tele.2015.12.003.

Tomczyk, Ł., Szotkowski, R., Fabiś, A., Wąsiński, A., Chudý, S.., \& Neumeister, P. (2015). Selected aspects of conditions in the use of new media as an important part of the training of teachers in the Czech Republic and Poland - differences, risks and threats. Education and Information Technologies, 22(3), 747-767. https://doi.org/10.1007/s10639-015-9455-8.

Tomczyk, Ł., Srokowski, Ł., \& Wassínski, A. (2016). Kompetencje w zakresie bezpieczeństwa cyfrowego w polskiej szkole. [Digital security competences in Polish schools]. Tarnów: Stowarzyszenie Miasta w Internecie.

Tomczyk, Ł., \& Oyelere, S. S. (2019). ICT for learning and inclusion in Latin America and Europe. Cracow: Pedagogical University.

Tsai, M.-J., \& Tsai, C.-C. (2003). Information searching strategies in web-based science learning: the role of Internet selfefficacy. Innovations in Education and Teaching International, 40(1), 43-50. https://doi.org/10.1080/1355800032000 038822.

Tsai, M.-J., \& Tsai, C.-C. (2010). Junior High School Students Internet Usage and Self-Efficacy: A Re-Examination of the Gender Gap. Computers \& Education, 54(4), 1182-1192. https://doi.org/10.1016/j.compedu.2009.11.004

Wakefield, J., \& Frawley, J. K. (2020). How does students' general academic achievement moderate the implications of social networking on specific levels of learning performance? Computers \& Education, 144, 103694. https://doi.org/10.1016/j. compedu.2019.103694

Wu, Y. T., \& Tsai, C. C. (2006). University Students' Internet Attitudes and Internet Self-Efficacy: AStudy at Three Universities in Taiwan. Cyberpsychology \& behavior, 9(4), 441-450. https://doi.org/10.1089/cpb.2006.9.441 


\section{Annex 1}

\section{Exploratory Factor Analysis}

\begin{tabular}{l}
$\frac{\text { Bartlett's test }}{\mathbf{X}^{2} \quad \mathbf{d f} \mathbf{p}}$ \\
$\frac{3924.827276 .000<.001}{}$ \\
\hline$\frac{\text { Chi-squared Test }}{\text { Value df } \mathbf{p}}$ \\
Model $315.631147<.001$ \\
\hline
\end{tabular}

\section{Factor Loadings}

\begin{tabular}{|c|c|c|c|c|c|c|c|}
\hline & $\begin{array}{c}\text { Factor } \\
1\end{array}$ & $\begin{array}{c}\text { Factor } \\
2\end{array}$ & $\begin{array}{c}\text { Factor } \\
3\end{array}$ & $\begin{array}{c}\text { Factor } \\
4\end{array}$ & $\begin{array}{c}\text { Factor } \\
5\end{array}$ & $\begin{array}{c}\text { Factor } \\
6\end{array}$ & Uniqueness \\
\hline Listening Internet radio & & & & & & 0.507 & 0.759 \\
\hline Watching internet TV & & & & & & 0.651 & 0.618 \\
\hline Playing games online & & & & & & 0.467 & 0.705 \\
\hline Watching videos on Internet & & & & & & & 0.716 \\
\hline Using Internet banking & & & 0.539 & & & & 0.696 \\
\hline Buying or ordering goods or services & & & 0.890 & & & & 0.284 \\
\hline Selling online & & & 0.540 & & & & 0.639 \\
\hline Searching information about travelling & & & & & & & 0.724 \\
\hline Using Internet for learning purpose at home & & & & & 0.663 & & 0.544 \\
\hline Studying school online courses & & & & 0.450 & & & 0.747 \\
\hline $\begin{array}{l}\text { Searching relevant sources on Internet to meet } \\
\text { learning tasks }\end{array}$ & & & & & 0.505 & & 0.703 \\
\hline $\begin{array}{l}\text { Using open e-learning courses (online courses) (e.g. } \\
\text { language, IT...) }\end{array}$ & & & & 0.666 & & & 0.528 \\
\hline Using paid e-learning courses (online courses) & & & & 0.661 & & & 0.547 \\
\hline Using Internet on mobile phone & 0.780 & & & & & & 0.482 \\
\hline Sending e-mails from mobile & 0.797 & & & & & & 0.394 \\
\hline Sending photos from mobile & 0.887 & & & & & & 0.299 \\
\hline Using smartphone as a mobile hotspot & 0.560 & & & & & & 0.536 \\
\hline Working with tablet & & & & & & & 0.790 \\
\hline Using cloud data synchronization & & & & & & & 0.698 \\
\hline Publishing messages on social networks & & 0.708 & & & & & 0.577 \\
\hline Using Internet streaming & & 0.470 & & & & & 0.668 \\
\hline Creating and editing videos for social networks & & 0.905 & & & & & 0.394 \\
\hline Using a file sharing service with others & & 0.582 & & & & & 0.590 \\
\hline $\begin{array}{l}\text { Participating as a member of a study group on a } \\
\text { social network }\end{array}$ & & & & & & & 0.807 \\
\hline Note. Applied rotation method is promax. & & & & & & & \\
\hline
\end{tabular}

\section{Factor Characteristics}

Sums. Loadings Proportion var. Cumulative

\begin{tabular}{lll}
\hline Factor 1 2.457 & 0.102 & 0.102 \\
Factor 2 1.879 & 0.078 & 0.181 \\
Factor 3 1.687 & 0.070 & 0.251 \\
Factor 4 1.370 & 0.057 & 0.308 \\
Factor 5 1.190 & 0.050 & 0.358 \\
Factor 6 0.971 & 0.040 & 0.398 \\
\hline
\end{tabular}


Eger, L., et al. (2020). How do first year university students use ICT in their leisure time and for learning purposes?, International Journal of Cognitive Research in Science, Engineering and Education (IJCRSEE), 8(2), 35-52

Additional fit indices

RMSEARMSEA 90\% confidence TLI BIC

$0.042 \quad 0.035-0.048$

$0.913-639.173$ 